\title{
Clinical factors associated with shorter durable response, and patterns of acquired resistance to first-line pembrolizumab monotherapy in PD-L1-positive non-small- cell lung cancer patients: a retrospective multicenter study
}

Kazutaka Hosoya ${ }^{1}$, Daichi Fujimoto ${ }^{1,2^{*}}$, Takeshi Morimoto ${ }^{3,4}$, Toru Kumagai $^{5}$, Akihiro Tamiya ${ }^{6}$, Yoshihiko Taniguchi ${ }^{6}$, Toshihide Yokoyama ${ }^{7}$, Tadashi Ishida ${ }^{7}$, Hirotaka Matsumoto ${ }^{8}$, Katsuya Hirano ${ }^{8}$, Ryota Kominami ${ }^{9}$, Keisuke Tomii ${ }^{1}$, Hidekazu Suzuki ${ }^{10}$, Tomonori Hirashima ${ }^{10}$, Satoshi Tanaka ${ }^{11}$, Junji Uchida ${ }^{11}$, Mitsunori Morita ${ }^{12}$, Masaki Kanazu ${ }^{13}$, Masahide Mori ${ }^{13}$, Kenji Nagata ${ }^{14}$, Ikue Fukuda ${ }^{14}$ and Motohiro Tamiya ${ }^{5}$

\begin{abstract}
Background: Despite the wide-spread use of immune checkpoint inhibitors (ICls) in cancer chemotherapy, reports on patients developing acquired resistance (AR) to ICI therapy are scarce. Therefore, we first investigated the characteristics associated with shorter durable responses of $\mathrm{ICl}$ treatment and revealed the clinical patterns of AR and prognosis of the patients involved.
\end{abstract}

Methods: We conducted a retrospective multi-center cohort study that included NSCLC patients with PD-L1 tumor proportion scores of $\geq 50 \%$ who received first-line pembrolizumab and showed response to the therapy. Among patients showing response, progression-free survival (PFS) was investigated based on different clinically relevant factors. AR was defined as disease progression after partial or complete response based on Response Evaluation Criteria in Solid Tumors. Among patients with AR, patterns of AR and post-progression survival (PPS) were investigated. Oligoprogression was defined as disease progression in up to 5 individual progressive lesions.

\footnotetext{
*Correspondence: daichi@wakayama-med.ac.jp

'Department of Respiratory Medicine, Kobe City Medical Center General

Hospital, 2-1-1 Minatojimaminamimachi, Chuo-ku, Kobe-shi, Hyogo 650-0047,

Japan

${ }^{2}$ Internal Medicine III, Wakayama Medical University, 811-1, Kimiidera,

Wakayama City, Wakayama 641-8509, Japan

Full list of author information is available at the end of the article
}

(c) The Author(s). 2021 Open Access This article is licensed under a Creative Commons Attribution 4.0 International License, which permits use, sharing, adaptation, distribution and reproduction in any medium or format, as long as you give appropriate credit to the original author(s) and the source, provide a link to the Creative Commons licence, and indicate if changes were made. The images or other third party material in this article are included in the article's Creative Commons licence, unless indicated otherwise in a credit line to the material. If material is not included in the article's Creative Commons licence and your intended use is not permitted by statutory regulation or exceeds the permitted use, you will need to obtain permission directly from the copyright holder. To view a copy of this licence, visit http://creativecommons.org/licenses/by/4.0/. The Creative Commons Public Domain Dedication waiver (http://creativecommons.org/publicdomain/zero/1.0/) applies to the data made available in this article, unless otherwise stated in a credit line to the data. 
(Continued from previous page)

Results: Among 174 patients who received first-line pembrolizumab, 88 showed response and were included in the study. Among these patients, 46 (52\%) developed AR. Patients with old age, poor performance status (PS), at least 3 metastatic organs, or bone metastasis showed significantly shorter PFS. Among 46 patients with AR, 32 (70\%) developed AR as oligoprogression and showed significantly longer PPS than those with non-oligoprogressive AR.

Conclusions: Patients with old age, poor PS, at least 3 metastatic organs, or bone metastasis showed shorter durable responses to pembrolizumab monotherapy. Oligoprogressive AR was relatively common and associated with better prognosis. Further research is required to develop optimal approaches for the treatment of these patients.

Keywords: Non-small cell lung cancer, Immunotherapy, Pembrolizumab, Acquired resistance, Oligoprogression

\section{Background}

Lung cancer is the leading cause of cancer-related deaths worldwide [1]. Non-small cell lung cancer (NSCLC) accounts for approximately $80 \%$ of all lung cancer cases, and the majority of these are diagnosed at an advanced stage [2, 3]. Recently, immune checkpoint inhibitors (ICIs) have been established as a therapy regimen for several types of malignancies, including advanced NSCL C.

Pembrolizumab, a fully humanized monoclonal antiprogrammed cell death 1 (PD-1) antibody, showed better treatment outcomes than platinum-based chemotherapy for previously untreated advanced NSCLC with positive programmed cell death ligand 1 (PD-L1) status [4, 5]. In particular, especially better treatment outcomes were observed for patients with PD-L1 tumor proportion score (TPS) $\geq 50 \%$. Hence, pembrolizumab monotherapy has become a standard first-line treatment, particularly for patients with PD-L1 TPS of $\geq 50 \%$.

In case of patients with NSCLC, ICI therapy has shown more durable responses than the existing cytotoxic agents [4-9]. In an earlier study, approximately $40 \%$ of patients with previously treated NSCLC having best overall response (BOR) of partial response (PR) or complete response (CR) to PD-1 axis inhibitor therapy showed sustained response after follow-up of at least 2 years [10]. However, despite durable response to PD-1 axis inhibitors, most patients show acquired resistance (AR). Therefore, there has been increasing attention on AR to improve the clinical outcomes of patients receiving PD-1 axis inhibitors. Nevertheless, there are few reports on the clinical features of AR to ICI therapy [11]. Understanding these clinical features is important in facilitating the appropriate treatment strategy for patients with AR.

The aim of our study was to characterize the clinical factors associated with shorter durable responses to ICI therapy and investigate the clinical patterns and prognosis of patients with AR to improve treatment strategy using ICIs.

\section{Methods \\ Study population}

We conducted a retrospective cohort study including patients with advanced NSCLC (unresectable stage IIIB or IV disease based on the 7th edition of TNM classification, excluding postoperative recurrence) with PD-L1 TPS of $\geq 50 \%$, who received pembrolizumab as a firstline therapy between February 1, 2017 and April 31, 2018 , and had initial response to it at any of the 11 participating institutions belonging to Hanshin Oncology clinical Problem Evaluation (HOPE) group. We censored the observation on July 31, 2019. The study protocol was approved by the review board of each institution and is registered with UMIN (University Hospital Medical Information Network Clinical Trials Registry of Japan; number 000032470).

In all the patients, the Eastern Cooperative Oncology Group (ECOG) performance status (PS) was evaluated just before the commencement of pembrolizumab therapy. PD-L1 expression was evaluated by immunohistochemical staining using the commercially available PDL1 IHC 22C3 pharmDx assay (Dako North America). The time between the date of pembrolizumab commencement and that of disease progression/death (progression-free survival or PFS) or death alone (overall survival or OS) was calculated for each patient. Tumor responses were assessed according to the Response Evaluation Criteria in Solid Tumors (RECIST), version 1.1. AR was defined as disease progression after PR or CR to pembrolizumab therapy based on RECIST, version 1.1 .

\section{Oligoprogression, number of organs with progressive lesions, 2nd PFS, and post-progression survival (PPS)}

Oligoprogression is a clinical state where tumor progression occurs in one or limited number of metastatic sites following previous systemic therapy wherein an initial response was observed. Previous studies have indicated that the concept of oligoprogression should be differentiated from oligometastases [12-14]. The concept of 
oligoprogression has been mainly proposed for patients with NSCLC with driver oncogenes and those receiving targeted therapy. The definition of oligoprogression varies among studies [15-19] and a consensus has not been reached even in ongoing clinical trials (NCT02756793 and NCT03256981). In accordance with the most popular definitions used in these studies, we defined oligoprogression as disease progression in up to 5 individual lesions. Multiple progressive lesions within a single organ or multiple progressive lymph nodes even within a single station of mediastinum were counted separately during radiological identification. Progression in truly unmeasurable lesions (such as pleural effusion, pericardiac effusion, leptomeningeal disease, etc.) was considered as progression in infinite numbers of lesions. In contrast, for determining the number of organs with progressive lesions, multiple progressive lesions within a single organ were compiled as progression in one organ. Moreover, thoracic, neck, or abdominal lymph nodes were considered as separate organs for each region in accordance with a previous study [11].

The 2nd PFS was defined as the time period between the 1st progressive disease (PD) and the 2nd PD (as defined by RECIST, considering the lesions at 1st PD as baseline) for patients who continued pembrolizumab treatment after the 1st PD. PPS was defined as the time period between the 1st PD and death of the patient regardless of receiving pembrolizumab after 1st PD.

\section{Statistical analyses}

We described continuous variables as mean and standard deviation (SD) and categorical variables as number and percent. PFS, 2nd PFS, OS, and PPS were calculated with Kaplan-Meier estimates, and compared using the log-rank test. We defined shorter durable responses as shorter PFS despite BOR of PR/CR. To investigate the potential factors associated with shorter durable responses, we constructed univariate Cox proportional hazard models for all the clinically relevant factors (age, sex, smoking status, ECOG PS, stage, the number of organs with metastatic lesions, the presence of specific metastatic organs [pleural effusion, bone, brain, adrenal grand and liver], and early immune-related adverse events [irAEs]) as identified by previous studies on ICIs $[4,6-9,20-23]$. For the number of metastatic organs, the cutoff was set to $\geq 3$ or $<3$, as described in previous studies $[20,21]$. In accordance with our previous study, we defined early irAEs as AEs with a potential immunemediated etiology that may require immune-modulating or endocrine therapy (such as rash, pyrexia, interstitial lung disease, hypothyroidism, etc.) occurring within 3 weeks after commencement of pembrolizumab [24]. Because of small number of events, we did not perform the multivariate models. For analyses, a two-tailed $P$ value of
$<.05$ was considered significant. Statistical analyses were conducted using JMP software (version 14; SAS Institute, Cary, NC, USA).

\section{Results}

Treatment outcomes of study patients.

The clinical characteristics and treatment outcomes of 174 patients with NSCLC with PD-L1 TPS of $\geq 50 \%$ who received first-line pembrolizumab between February 1, 2017 and April 31, 2018 are summarized in eTable 1 and eFigure 1 in the Supplement, respectively. Among these, a total of 88 patients responding to first-line pembrolizumab therapy were included in the present study (Table 1).

During the median follow-up of 19.8 months (range: 5.4-29.2) for all the 88 patients, 46 (52\%) developed AR. The patient response is summarized as a flow chart in eFigure 2 in the Supplement. The median PFS of the study patients was 18.4 months (95\% CI: 13.6-22.1) (Fig. 1a). The median duration of follow-up for the patients with and without AR was 18.9 months (range: 5.4-28.5) and 22.0 months (range: 10.0-29.2), respectively. The OS data was immature, because only 21 events $(24 \%)$ had occurred by the date of data cutoff.

\section{Clinical factors associated with shorter durable responses of pembrolizumab}

The following groups of patients were significantly associated with shorter PFS: old age ( $\geq 75$ years; median, 10.0 versus 20.6 months; hazard ratio $[\mathrm{HR}], 1.96 ; 95 \% \mathrm{CI}$, $1.11-3.47 ; P=.020)$, poor ECOG PS $(2-4$; median, 8.7 versus 19.6 months; $\mathrm{HR}, 2.65 ; 95 \% \mathrm{CI}, 1.24-5.17 ; P=$ .007 ), with at least 3 metastatic organs (median, 16.4 versus 20.6 months; HR, 2.37; 95\% CI, 1.20-4.41; $P=.009$ ), and with bone metastasis (median, 9.3 versus 23.2 months; HR, 3.71, 95\% CI, 2.04-6.73; $P<.001$ ) (Table 2). The Kaplan-Meier curves are shown in Fig. 1b-e. Other clinical factors, such as sex, smoking status, histology, stage, metastatic organs other than bone, and early irAEs did not show any significant association with PFS (eFigure 3 in the Supplement).

\section{Patterns of AR}

The numbers of individual progressive lesions are summarized in Fig. 2. Among 46 patients with AR, 18 (39\%) patients had one progressive lesion, 6 (13\%) had 2 lesions, 4 (9\%) had 3 lesions, 2 (4\%) had 4 lesions, 2 (4\%) had 5 lesions, and 14 (30\%) had at least 6 progressive lesions. In total, oligoprogression was seen in 32 (70\%) patients.

Patients with AR were classified into three categories: progression in only pre-existing (before commencing pembrolizumab) lesions, progression in only new lesions, or both. In oligoprogressive AR patients 21/7/4 patients 
Table 1 Patient characteristics

\begin{tabular}{|c|c|}
\hline Characteristics & $(n=88)$ \\
\hline Age (years, mean $\pm S D$ ) & $69.4 \pm 8.8$ \\
\hline \multicolumn{2}{|l|}{ Sex, n (\%) } \\
\hline male & $74(84)$ \\
\hline female & $14(16)$ \\
\hline \multicolumn{2}{|l|}{ Smoking status, n (\%) } \\
\hline never smoker & $10(11)$ \\
\hline smoker (current or former) & $78(89)$ \\
\hline \multicolumn{2}{|l|}{ ECOG PS, n (\%) } \\
\hline $0-1$ & $75(85)$ \\
\hline $2-4$ & $13(15)$ \\
\hline \multicolumn{2}{|l|}{ Histology, n (\%) } \\
\hline Squamous & $24(27)$ \\
\hline Non-squamous & $64(73)$ \\
\hline \multicolumn{2}{|l|}{ Stage, n (\%) } \\
\hline III B & $21(24)$ \\
\hline IV & $67(76)$ \\
\hline \multicolumn{2}{|l|}{$E G F R, \mathrm{n}(\%)$} \\
\hline mutant & $3(3)$ \\
\hline wild type & $78(89)$ \\
\hline not investigated & $7(8)$ \\
\hline \multicolumn{2}{|l|}{$A L K, \mathrm{n}(\%)$} \\
\hline rearranged & 0 \\
\hline not rearranged & $80(91)$ \\
\hline not investigated & $8(9)$ \\
\hline \multicolumn{2}{|l|}{ Number of metastatic organs, $\mathrm{n}(\%)$} \\
\hline$<3$ & $72(82)$ \\
\hline$\geq 3$ & $16(18)$ \\
\hline \multicolumn{2}{|l|}{ Metastatic organs, n (\%) } \\
\hline Pleural effusion or dissemination & $21(24)$ \\
\hline Bone & $26(30)$ \\
\hline Brain & $11(13)$ \\
\hline Adrenal grand & $14(16)$ \\
\hline Liver & $14(16)$ \\
\hline
\end{tabular}

ALK anaplastic lymphoma kinase, ECOG PS Eastern Cooperative Oncology Group performance status, EGFR epidermal growth factor receptor, SD standard deviation

showed the above progression patterns and in nonoligoprogressive AR patients 6/3/5 patients showed as such.

Regarding the number of organs with progressive lesions, 26 (57\%) of 46 patients developed it in one organ, $11(24 \%)$ in two organs, and $9(20 \%)$ in three or more organs (eFigure 4 in the Supplement). The common organs associated with AR were the lungs $(n=22,52 \%)$, thoracic lymph node $(n=16,35 \%)$, and bone $(n=10,22 \%)$. A total of 20 patients (43\%) developed AR in the lymph nodes.
Treatment and prognosis of patients with $A R$

Among the 46 patients with AR, 19 (41\%) received subsequent platinum-based doublet (with or without antivascular endothelial growth factor agent) therapy after pembrolizumab, 7 (15\%) continued pembrolizumab therapy beyond 1st PD, 6 (13\%) received subsequent monotherapy of cytotoxic agents, 1 (2\%) received EGFRtyrosine kinase inhibitor therapy, and 13 (28\%) received only best-supportive care. In addition, 7 patients (15\%), who developed AR as oligoprogression, received local ablative therapy (radiation therapy) for all lesions of AR. Four patients continued pembrolizumab and did not receive local ablative therapy, and none of them showed tumor shrinkage again and that PD was considered as true PD (not pseudoprogression).

The PPS in all the patients with AR $(n=46)$ was 15.1 months (95\% CI: 11.5-not reached). It was significantly longer in patients with oligoprogressive AR than in those with non-oligoprogressive AR: 16.2 months, (95\% CI: 11.5-not reached) versus 11.5 months (95\% CI: 2.5-not reached), HR, 0.31; 95\% CI, 0.11-0.92; $P=.035$ (Fig. 3). Moreover, the median 2nd PFS was not reached (95\% CI: 7.7-not reached) in patients with AR who received local ablative radiation therapy for all lesions of AR and continued pembrolizumab therapy beyond 1st progression $(n=4)$ (eFigure 5 in the Supplement).

\section{Discussion}

We revealed that factors such as old age, poor PS, or metastatic organs $\geq 3$ were associated with shorter durable responses of first-line pembrolizumab monotherapy in NSCLC patients who showed response to the therapy. Further, oligoprogression was found to be relatively common and associated with better prognosis. To the best of our knowledge, this is the first study to explore the clinical factors associated with the shorter durable responses of ICI therapy and the largest cohort study performed in patients with AR.

The factors that were found to be associated with shorter PFS in our study have also been reported by previous studies [20, 21, 25-28]; however, these studies mainly focused on primary resistance. To date, no study has investigated the clinical factors associated with AR to ICI therapy. Although the clinical factors associated with and mechanisms underlying AR to ICI therapy are not fully understood, old age and poor PS (frailty) have been shown to be associated with immunosuppressive activity, which inhibits ICI-induced activation of the immune system $[29,30]$. In addition, a high antigen burden is shown to have negative effect on the activation of $\mathrm{T}$ cells, as indicated by a previous study on viral infection [31].

We revealed that the majority of AR occurred as oligoprogression $(70 \%)$. In previous studies, the proportion of 


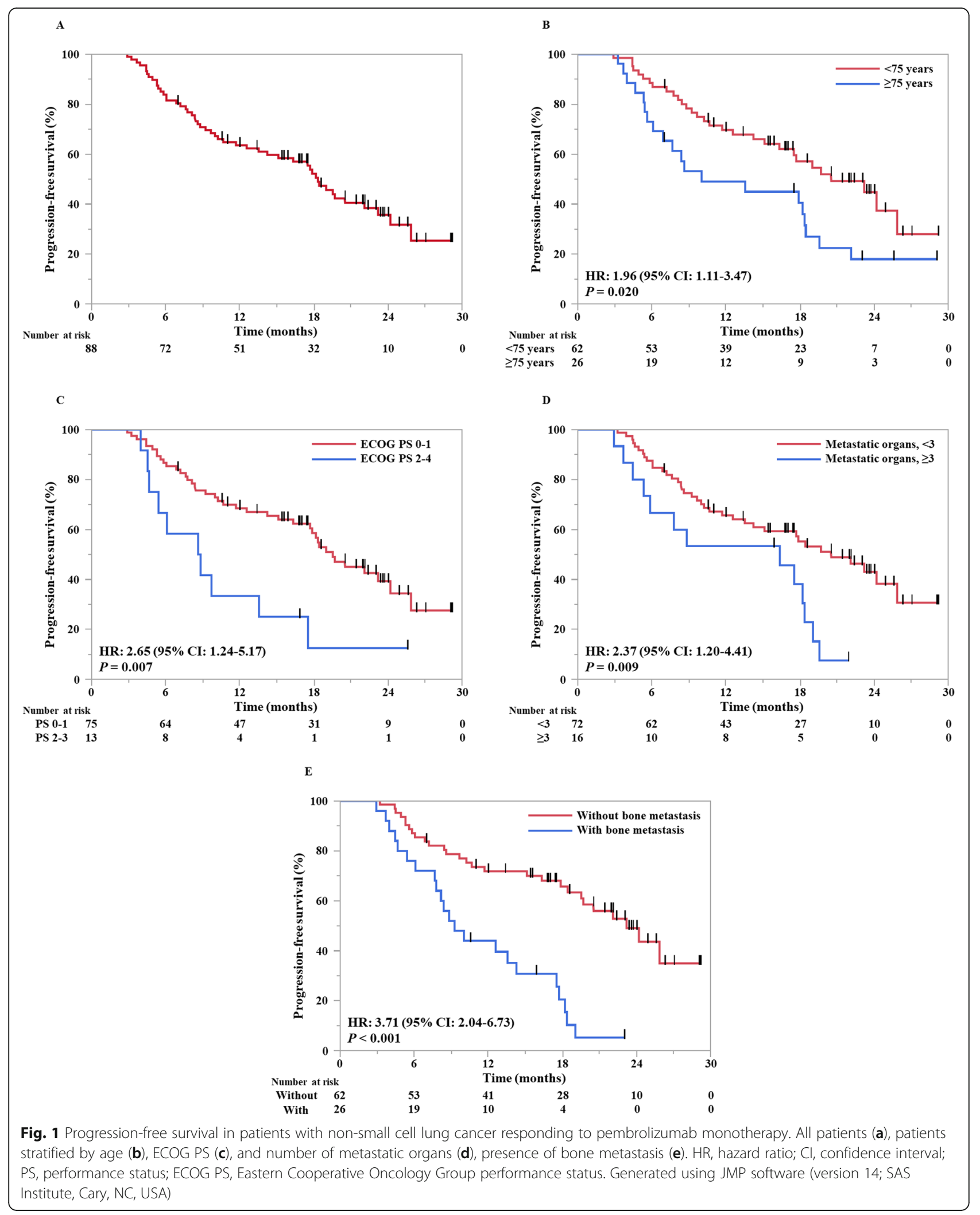


Table 2 Univariate analyses for progression-free survival

\begin{tabular}{|c|c|c|c|c|}
\hline Characteristics & $\begin{array}{l}\text { No. (\%) } \\
(n=88)\end{array}$ & $\begin{array}{l}\text { Median } \\
\text { PFS, } \\
\text { month }\end{array}$ & $\mathrm{HR}(95 \% \mathrm{Cl})$ & $P$ value \\
\hline \multicolumn{5}{|l|}{ Age, years } \\
\hline$\geq 75$ & $26(30)$ & 10.0 & $1.96(1.11-3.47)$ & $0.020^{*}$ \\
\hline$<75$ & $62(70)$ & 20.6 & Reference & \\
\hline \multicolumn{5}{|l|}{ Sex } \\
\hline female & $14(16)$ & 17.5 & $1.02(0.42-2.14)$ & 0.955 \\
\hline male & $74(84)$ & 18.4 & Reference & \\
\hline \multicolumn{5}{|l|}{ Smoking status } \\
\hline smoker (current or former) & $78(89)$ & 18.2 & $1.25(0.57-3.29)$ & 0.615 \\
\hline never smoker & $10(11)$ & 18.4 & Reference & \\
\hline \multicolumn{5}{|l|}{ ECOG PS } \\
\hline $2-4$ & $13(15)$ & 8.7 & $2.65(1.24-5.17)$ & $0.007^{*}$ \\
\hline $0-1$ & $75(85)$ & 19.6 & Reference & \\
\hline \multicolumn{5}{|l|}{ Histology } \\
\hline Squamous & $24(27)$ & 15.2 & $1.17(0.63-2.17)$ & 0.624 \\
\hline Non-squamous & $64(73)$ & 18.1 & Reference & \\
\hline \multicolumn{5}{|l|}{ Stage } \\
\hline IV & $67(76)$ & 17.7 & $1.19(0.63-2.45)$ & 0.605 \\
\hline$\| \mathrm{IIB}$ & $21(24)$ & 19.7 & Reference & \\
\hline \multicolumn{5}{|l|}{ Pleural effusion or dissemination } \\
\hline present & $21(24)$ & 18.5 & $0.88(0.47-1.63)$ & 0.685 \\
\hline absent & $67(76)$ & 18.2 & Reference & \\
\hline \multicolumn{5}{|l|}{ Bone metastasis } \\
\hline present & $26(30)$ & 9.3 & $3.71(2.04-6.73)$ & $<0.001^{*}$ \\
\hline absent & $62(70)$ & 23.2 & Reference & \\
\hline \multicolumn{5}{|l|}{ Brain metastasis } \\
\hline present & $11(13)$ & 19.6 & $0.93(0.39-2.18)$ & 0.858 \\
\hline absent & $77(88)$ & 18.4 & Reference & \\
\hline \multicolumn{5}{|l|}{ Adrenal grand metastasis } \\
\hline present & $14(16)$ & 18.4 & $0.95(0.44-2.02)$ & 0.886 \\
\hline absent & $74(84)$ & 18.2 & Reference & \\
\hline \multicolumn{5}{|l|}{ Liver metastasis } \\
\hline present & $14(16)$ & 19.6 & $0.78(0.35-1.75)$ & 0.543 \\
\hline absent & $74(84)$ & 17.9 & Reference & \\
\hline \multicolumn{5}{|l|}{ Number of metastatic organs } \\
\hline$\geq 3$ & $16(18)$ & 16.4 & $2.37(1.20-4.41)$ & $0.009^{*}$ \\
\hline$<3$ & $72(82)$ & 20.6 & Reference & \\
\hline \multicolumn{5}{|l|}{ Early irAEs } \\
\hline present & $41(47)$ & 17.5 & $1.05(0.60-1.84)$ & 0.857 \\
\hline absent & 47 (53) & 19.6 & Reference & \\
\hline
\end{tabular}

*P<0.05

PFS progression-free survival, ECOG PS Eastern Cooperative Oncology Group performance status, irAE immune-related adverse event, HR hazard ratio, PFS progression-free survival 


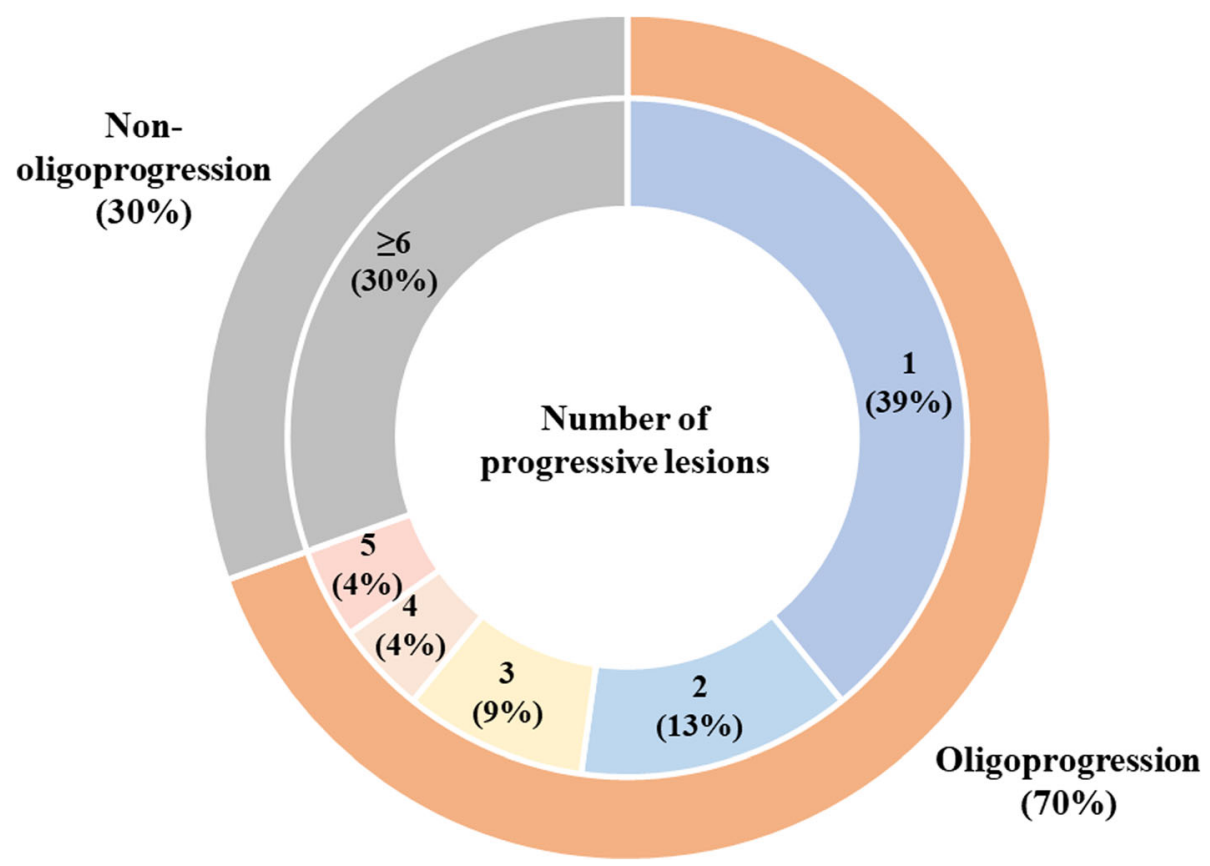

Fig. 2 Pie-chart summarizing the number of progressive lesions in patients with acquired resistance

oligoprogression was reported to be $15-47 \%$ in patients with NSCLC with driver oncogenes and who showed AR to targeted therapy $[13,17,18]$, which is lower than that reported in our study. This may be attributed to the difference in the definition of oligoprogression and in the treatment class. The definition of oligoprogression has yet to reach consensus, and we adopted one definition used in multiple studies, as mentioned above. Stratifying by this definition, patients with oligoprogressive AR showed longer PPS, indicative of the validity of our

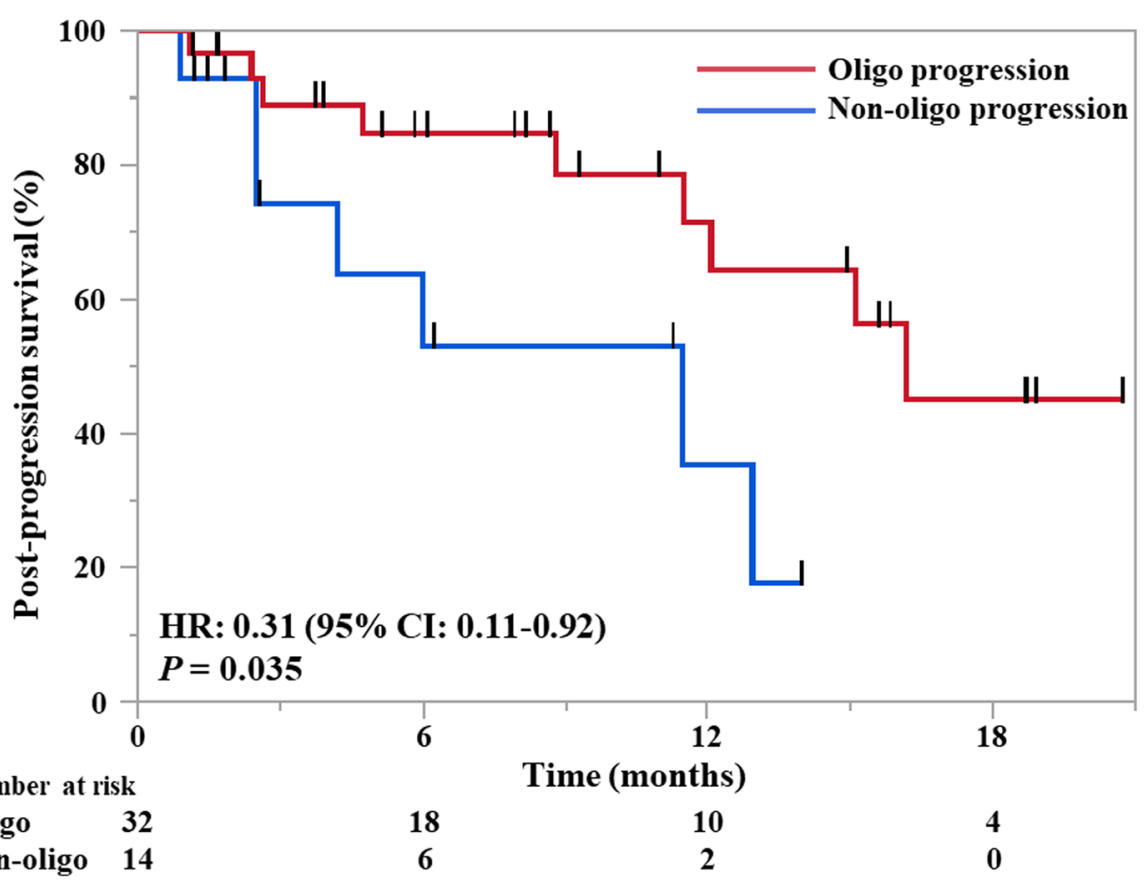

Fig. 3 Post-progression survival of patients with acquired resistance, stratified based on presence or absence of oligoprogression. HR, hazard ratio; Cl, confidence interval. Generated using JMP software (version 14; SAS Institute, Cary, NC, USA) 
definition in discriminating distinct populations. Further discussions on the definition are warranted to plan clinical trials for oligoprogressive AR patients and develop better treatment strategies for these patients.

Oligoprogression after ICI therapy has been reported previously only by an individual report that considered a smaller number of samples $(n=26)$ [11]. However, our study included a greater number of samples and identified patients with clearly defined oligoprogression. Moreover, the previous study included patients regardless of therapeutic agents (including PD-L1 and cytotoxic Tlymphocyte-associated antigen 4 [CTLA-4] axis inhibitor alone or in combination) and treatment lines [11]. In contrast, our study included more homogenous patients receiving only first-line pembrolizumab monotherapy.

The current study further revealed that many patients developed AR in only one organ (57\%), which is in agreement with an earlier study showing development of AR in only one organ for $54 \%$ of the patients [11]. In addition, the previous report emphasized the development of AR in the lymph nodes for majority of the patients (77\%). However, in the current study, only $43 \%$ of the patients developed AR in the lymph nodes. A probable reason for this discrepancy could be attributed to the difference in treatment lines and agents. The patterns of AR to ICI therapy need to be evaluated in future studies.

The survival analysis of patients with AR revealed that oligoprogressive patients showed longer PPS than their non-oligo (or systemic) progressive counterparts. Moreover, although limited in number, oligoprogressive patients who received local ablative radiotherapy and continued pembrolizumab beyond progression showed promising 2nd PFS in our cohort. Similarly, local ablative therapy after targeted therapy for oligoprogressive NSCLC patients has shown clinical efficacy previously [17, 19]. Local ablative radiation therapy in combination with ICIs has been shown to be more promising owing to synergetic effect called abscopal effect [32, 33], and is currently being considered in clinical trials $[34,35]$. Because of the high frequency of oligoprogressive disease, further studies are needed to investigate the efficacy of local ablative therapy in patients with oligoprogressive AR to ICI therapy.

The mechanisms underlying AR to ICI therapy are not fully understood; however, some of them were partially in common with primary resistance and have been explained in different studies [36-39]. These mechanisms are roughly classified as follows: intrinsic cancer cell resistance, intrinsic $\mathrm{T}$ cell resistance, and extrinsic resistance. Intrinsic cancer cell resistance represents loss of immunogenicity of cancer cells [40], which were suggested to result from alterations, such as loss of beta-2-microglobullin (B2M) function [41, 42] and phosphatase and tensin homolog deleted on chromosome 10 (PTEN) function [43]. Intrinsic T cell resistance represents immune adaptation caused by upregulation of other immune checkpoint molecules such as CTLA-4, lymphocyte activation gene 3 (LAG-3) or T-cell immunoglobulin and mucin domain 3 (TIM-3) [44, 45]. Extrinsic resistance represents modulation of tumor microenvironment (TME) through infiltration of immunosuppressive cells, such as regulatory $\mathrm{T}$ cells [46] and myeloid-derived suppressor cells (MDSCs) [47]. We could not explain the reason for the high frequency and better prognosis of patients with oligoprogressive AR in our study, and the underlying mechanisms should be explored in further studies.

The treatment outcomes in our entire cohort were in agreement with those reported in previous clinical trials. The objective response rate and median PFS of first-line PD-1 axis inhibitor monotherapy in patients with NSCL $C$ with PD-L1 TPS of $\geq 50 \%$ were reported to be $37-58 \%$ and 5.6-12.5 months, respectively, in previous studies [4, $5,48]$; these values were in agreement with the findings in our entire cohort, including all the patients who received pembrolizumab. Further, the median time to response and duration of response for PD-1 axis inhibitors were reported to be $2.1-2.2$ and 16.3-25.2 months, respectively, in previous phase 3 trials $[5-9,49]$. These results were in agreement with our study, wherein the median PFS of patients with response to first-line pembrolizumab treatment was 18.4 months.

The present study has several limitations. First, although our study included the largest multicenter cohort of its kind and provided novel findings, it was retrospective in nature. This limitation includes the retrospective assessment of tumor responses and metastatic lesions at diagnosis of NSCLC. Second, biomarkers other than PD-L1 expression, such as tumor mutation burden, were not investigated. However, these biomarkers are currently under active investigation because they produced conflicting results regarding their clinical benefit. Third, the distribution of treatment patterns after progression was different between oligoprossive and non-oligoprogressive AR patients. The proportions of oligoprossive and nonoligoprogressive AR patients who received only the best supportive care were 22 and 43\%, respectively, which may have influenced the analysis of PPS. Fourth, we focused on $\mathrm{AR}$ and did not collect data on primary resistance. We could not determine whether the clinical features of AR revealed were specific to AR or in common with primary resistance and AR.

\section{Conclusions}

We revealed that old age, poor PS, or at least 3 metastatic organs were associated with shorter durable responses to pembrolizumab. Further, patients with oligoprogressive AR were relatively common and associated with better prognosis. We believe that these findings provide a scope for improving ICI therapy and suggest new directions for clinical studies. 


\section{Abbreviations}

AR: Acquired resistance; B2M: Beta-2-microglobullin; BOR: Best overall response; CR: Complete response; CTLA-4: Cytotoxic T-lymphocyte-associated antigen 4; DCR: Disease control rate; ECOG PS: Eastern Cooperative Oncology Group performance status; EGFR: Epidermal growth factor receptor; ICI: Immune checkpoint inhibitor; irAE: Immune-related adverse event; LAG3: Lymphocyte activation gene 3; MDSC: Myeloid-derived suppressor cell; NSCLC: Non-small cell lung cancer; ORR: Overall response rate; OS: Overall survival; PD-1: Programmed cell death 1; PD-L1: Programmed cell death ligand 1; PFS: Progression-free survival; PR: Partial response; PTEN: Tensin homolog deleted on chromosome 10; RECIST: Response Evaluation Criteria in Solid Tumors; TIM-3: T-cell immunoglobulin and mucin domain 3; TME: Tumor microenvironment; TPS: Tumor proportion score

\section{Supplementary Information}

The online version contains supplementary material available at https://doi. org/10.1186/s12885-021-08048-4.

\section{Additional file 1.}

Additional file 2 Supplementary Fig. 1. Progression-free survival (A) and overall survival (B) in all patients who received first-line pembrolizumab. Generated using JMP software (version 14; SAS Institute, Cary, NC, USA). Supplementary Fig. 2. Flow chart of the study patients. Supplementary Fig. 3. Progression-free survival (PFS) in patients with response, stratified by sex (A), smoking history (B), histology (C), stage (D), and presence of pleural effusion or dissemination (E), brain metastasis ( $\mathrm{F}$ ), adrenal grand metastasis $(\mathrm{G})$, liver metastasis $(\mathrm{H})$, early immune-related adverse events (irAEs) (I). Generated using JMP software (version 14; SAS Institute, Cary, NC, USA). Supplementary Fig. 4. Pie-chart summarizing the organs with progressive lesions. Patients with progression in one organ (blue), 2 organs (orange), or 3 or more organs (grey). Supplementary Fig. 5. The 2nd progression-free survival of patients who developed acquired resistance, received local ablative therapy and pembrolizumab therapy beyond 1st PD. Generated using JMP software (version 14; SAS Institute, Cary, NC, USA).

\section{Additional file 3.}

\section{Acknowledgements}

We are grateful to all patients and investigators who participated in this study.

\section{Authors' contributions}

$\mathrm{KH} 1$ and DF had full access to all of the data in the study and take responsibility for the integrity of the data and the accuracy of the data analysis. DF and MT were involved in the study concepts and design. All authors (KH1, DF, TM, TK, AT, YT, TY, TI, HM, KH2, RK, KT, HS, TH, ST, JU, MM1, MK, MM2, KN, IF and MT) involved in the acquisition, analysis and interpretation of data. DF and TM supervised the analysis. KH1 and DF involved in the draft of the manuscript. All authors read, critically revised and approved the manuscript.

\section{Funding}

This research did not receive any specific grant from funding agencies in the public, commercial, or not-for-profit sectors.

\section{Availability of data and materials}

The datasets generated during and/or analysed during the current study are available from the corresponding author on reasonable request.

\section{Declarations}

\section{Ethics approval and consent to participate}

All procedures performed in studies involving human participants were in accordance with the ethical standards of the institutional and/or national research committee and with the 1964 Helsinki declaration and its later amendments or comparable ethical standards. This retrospective study was approved by institutional review board in each institution. (Institutional Review Board in Osaka International Cancer Institute, the Research Ethics Review Committee in Kobe City Medical Center General Hospital, the Clinical
Research Review Committee in National Hospital Organization Kinki-Chuo Chest Medical Center, the Medical ethics committee in Kurashiki Central Hospital, the Ethics Committee in Hyogo Prefectural Amagasaki General Medical Center, the Clinical Research Review Committee in National Hospital Organization Himeji Medical Center, the Medical Research Ethics Committee in Osaka Habikino Medical Center, the Clinical Research Review Committee in Osaka General Medical Center, the Clinical Research Review Committee in Kobe City Medical Center West Hospital, the Clinical Research Review Committee in National Hospital Organization Osaka Toneyama Medical Center, and the Research Ethics Committee in Itami City Hospital) The ethics committees waived the need for formal consents from the participants.

\section{Consent for publication}

Not applicable.

\section{Competing interests}

Drs. Hosoya, Fujimoto, M. Tamiya, A. Tamiya, Hirano, and Mori have received lecture fees from Taiho Pharmaceutical Co., Ltd. (Tokyo, Japan) and Merck Sharp \& Dohme, Corp. (Tokyo, Japan). Drs. Yokoyama and Hirashima have received lecture fees from Taiho Pharmaceutical Co., Ltd. (Tokyo, Japan). Drs. Kumagai, Taniguchi, Ishida, and Kanazu have received lecture fees from Merck Sharp \& Dohme, Corp. (Tokyo, Japan). The remaining authors have no conflicts of interest to declare

\section{Author details}

${ }^{1}$ Department of Respiratory Medicine, Kobe City Medical Center General Hospital, 2-1-1 Minatojimaminamimachi, Chuo-ku, Kobe-shi, Hyogo 650-0047, Japan. ${ }^{2}$ Internal Medicine III, Wakayama Medical University, 811-1, Kimiidera, Wakayama City, Wakayama 641-8509, Japan. ${ }^{3}$ Clinical Research Center, Kobe City Medical Center General Hospital, 2-1-1 Minatojimaminamimachi, Chuo-ku, Kobe-shi, Hyogo 650-0047, Japan. ${ }^{4}$ Department of Clinical Epidemiology, Hyogo College of Medicine, 1-1 Mukogawa, Nishinomiya, Hyogo 663-8501, Japan. ${ }^{5}$ Department of Thoracic Oncology, Osaka International Cancer Institute, 3-1-69 Otemae, Chuo-ku, Osaka 541-8567, Japan. ${ }^{6}$ Department of Internal Medicine, National Hospital Organization Kinki-Chuo Chest Medical Center, 1180, Nagasone-cho, Kita-ku, Sakai-shi, Osaka 591-8555, Japan. ${ }^{7}$ Department of Respiratory Medicine, Kurashiki Central Hospital, 1-1-1, Miwa, Kurashiki-shi, Okayama 710-8602, Japan. ${ }^{8}$ Department of Respiratory Medicine, Hyogo Prefectural Amagasaki General Medical Center, 2-17-77, Higashi-Naniwa-Cho, Amagasaki-shi, Hyogo 660-8550, Japan. ${ }^{9}$ Department of Respiratory Medicine, Himeji Medical Center, 68, Honmachi, Himeji-shi, Hyogo 670-8520, Japan. ${ }^{10}$ Department of Thoracic Oncology, Osaka Habikino Medical Center, 3-7-1, Habikino, Habikino-shi, Osaka 583-8588, Japan. "1Department of Respiratory Medicine, Osaka General Medical Center, 3-1-56, Bandai-Higashi, Sumiyoshi-ku, Osaka-shi, Osaka 558-8558, Japan. ${ }^{12}$ Department of Respiratory Medicine, Kobe City Medical Center West Hospital, 2-4, Ichiban-cho, Nagata-ku, Kobe-shi, Hyogo 653-0013, Japan. ${ }^{13}$ Department of Thoracic Oncology, National Hospital Organization Osaka Toneyama Medical Center, 5-1-1, Toneyama, Toyonaka-shi, Osaka 560-0045, Japan. ${ }^{14}$ Department of Respiratory Medicine, Itami City Hospital, 1-100, Koyaike, Itami-shi, Hyogo 664-8540, Japan.

Received: 11 November 2020 Accepted: 16 March 2021

Published online: 01 April 2021

\section{References}

1. Siegel RL, Miller KD, Jemal A. Cancer statistics, 2017. CA Cancer J Clin. 2017; 67(1):7-30. https://doi.org/10.3322/caac.21387.

2. Morgensztern D, Ng SH, Gao F, Govindan R. Trends in stage distribution for patients with non-small cell lung cancer: a National Cancer Database survey. J Thorac Oncol. 2010;5(1):29-33. https://doi.org/10.1097/JTO.0b013e3181 c5920c.

3. Molina JR, Yang P, Cassivi SD, Schild SE, Adjei AA. Non-small cell lung cancer: epidemiology, risk factors, treatment, and survivorship. Mayo Clin Proc. 2008;83(5):584-94. https://doi.org/10.1016/S0025-6196(11)60735-0.

4. Reck M, Rodriguez-Abreu D, Robinson AG, Hui R, Csoszi T, Fulop A, Gottfried M, Peled N, Tafreshi A, Cuffe S, et al. Pembrolizumab versus chemotherapy for PD-L1-positive non-small-cell lung Cancer. N Engl J Med. 2016;375(19): 1823-33. https://doi.org/10.1056/NEJMoa1606774. 
5. Mok TSK, Wu YL, Kudaba I, Kowalski DM, Cho BC, Turna HZ, Castro G Jr, Srimuninnimit V, Laktionov KK, Bondarenko I, Kubota K, Lubiniecki GM, Zhang J, Kush D, Lopes G, Adamchuk G, Ahn MJ, Alexandru A, Altundag O, Alyasova A, Andrusenko O, Aoe K, Araujo A, Aren O, Arrieta Rodriguez O, Ativitavas T, Avendano O, Barata F, Barrios CH, Beato C, Bergstrom P, Betticher D, Bolotina L, Bondarenko I, Botha M, Buddu S, Caglevic C, Cardona A, Castro G Jr, Castro H, Cay Senler F, Cerny CAS, Cesas A, Chan GC, Chang J, Chen G, Chen X, Cheng S, Cheng Y, Cherciu N, Chiu CH, Cho BC, Cicenas S, Ciurescu D, Cohen G, Costa MA, Danchaivijitr P, de Angelis F, de Azevedo SJ, Dediu M, Deliverski T, de Marchi PRM, de The Bustamante Valles F, Ding Z, Doganov B, Dreosti L, Duarte R, Edusma-Dy R, Emelyanov S, Erman M, Fan Y, Fein L, Feng J, Fenton D, Fernandes G, Ferreira C, Franke FA, Freitas H, Fujisaka Y, Galindo H, Galvez C, Ganea D, Gil N, Girotto G, Goker E, Goksel T, Gomez Aubin G, Gomez Wolff L, Griph H, Gumus M, Hall J, Hart G, Havel L, He J, He Y, Hernandez Hernandez C, Hespanhol V, Hirashima T, Ho CMJ, Horiike A, Hosomi Y, Hotta K, Hou M, How SH, Hsia TC, Hu Y, Ichiki M, Imamura F, Ivashchuk O, Iwamoto Y, Jaal J, Jassem J, Jordaan C, Juergens RA, Kaen D, Kalinka-Warzocha E, Karaseva N, Karaszewska B, Kazarnowicz A, Kasahara K, Katakami N, Kato T, Kawaguchi T, Kim JH, Kishi K, Kolek V, Koleva M, Kolman P, Koubkova L, Kowalyszyn R, Kowalski D, Koynov K, Ksienski D, Kubota K, Kudaba I, Kurata T, Kuusk G, Kuzina L, Laczo I, Ladrera GEl, Laktionov K, Landers G, Lazarev S, Lerzo G, Lesniewski Kmak K, Li W, Liam CK, Lifirenko I, Lipatov O, Liu X, Liu Z, Lo SH, Lopes V, Lopez K, Lu S, Martinengo G, Mas L, Matrosova M, Micheva R, Milanova Z, Miron L, Mok T, Molina M, Murakami S, Nakahara Y, Nguyen TQ, Nishimura T, Ochsenbein A, Ohira T, Ohman R, Ong CK, Ostoros G, Ouyang X, Ovchinnikova E, Ozyilkan O, Petruzelka L, Pham XD, Picon P, Piko B, Poltoratsky A, Ponomarova O, Popelkova P, Purkalne G, Qin S, Ramlau R, Rappaport B, Rey F, Richardet E, Roubec J, Ruff P, Rusyn A, Saka H, Salas J, Sandoval M, Santos L, Sawa T, Seetalarom K, Seker M, Seki N, Seolwane F, Shepherd L, Shevnya S, Shimada AK, Shparyk Y, Sinielnikov I, Sirbu D, Smaletz O, Soares JPH, Sookprasert A, Speranza G, Srimuninnimit V, Sriuranpong V, Stara Z, Su WC, Sugawara S, Szpak W, Takahashi K, Takigawa N, Tanaka H, Tan Chun Bing J, Tang Q, Taranov P, Tejada H, Tho LM, Torii Y, Trukhyn D, Turdean M, Turna H, Ursol G, Vanasek J, Varela M, Vallejo M, Vera L, Victorino AP, Vlasek T, Vynnychenko I, Wang B, Wang J, Wang K, Wu Y, Yamada K, Yang CH, Yokoyama T, Yokoyama T, Yoshioka H, Yumuk F, Zambrano A, Zarba JJ, Zarubenkov O, Zemaitis M, Zhang L, Zhang L, Zhang X, Zhao J, Zhou C, Zhou J, Zhou Q, Zippelius A. Pembrolizumab versus chemotherapy for previously untreated, PD-L1-expressing, locally advanced or metastatic non-small-cell lung cancer (KEYNOTE-042): a randomised, open-label, controlled, phase 3 trial. Lancet. 2019;393(10183):1819-30. https://doi.org/10.1016/S0140-6736(18)32409-7.

6. Borghaei H, Paz-Ares L, Horn L, Spigel DR, Steins M, Ready NE, Chow LQ, Vokes EE, Felip E, Holgado E, Barlesi F, Kohlhäufl M, Arrieta O, Burgio MA Fayette J, Lena H, Poddubskaya E, Gerber DE, Gettinger SN, Rudin CM, Rizvi N, Crinò L, Blumenschein GR Jr, Antonia SJ, Dorange C, Harbison CT, Graf Finckenstein F, Brahmer JR. Nivolumab versus Docetaxel in advanced nonsquamous non-small-cell lung Cancer. N Engl J Med. 2015;373(17):162739. https://doi.org/10.1056/NEJMoa1507643.

7. Brahmer J, Reckamp KL, Baas P, Crino L, Eberhardt WE, Poddubskaya E, Antonia S, Pluzanski A, Vokes EE, Holgado E, et al. Nivolumab versus Docetaxel in advanced squamous-cell non-small-cell lung Cancer. N Engl J Med. 2015;373(2):123-35. https://doi.org/10.1056/NEJMoa1504627.

8. Herbst RS, Baas P, Kim DW, Felip E, Perez-Gracia JL, Han JY, Molina J, Kim JH, Arvis CD, Ahn MJ, et al. Pembrolizumab versus docetaxel for previously treated, PD-L1-positive, advanced non-small-cell lung cancer (KEYNOTE-010): a randomised controlled trial. Lancet. 2016;387(10027):1540-50. https://doi. org/10.1016/S0140-6736(15)01281-7.

9. Rittmeyer A, Barlesi F, Waterkamp D, Park K, Ciardiello F, von Pawel J, Gadgeel SM, Hida T, Kowalski DM, Dols MC, Cortinovis DL, Leach J, Polikoff J, Barrios C, Kabbinavar F, Frontera OA, de Marinis F, Turna H, Lee JS, Ballinger M, Kowanetz M, He P, Chen DS, Sandler A, Gandara DR, OAK Study Group. Atezolizumab versus docetaxel in patients with previously treated non-small-cell lung cancer (OAK): a phase 3, open-label, multicentre randomised controlled trial. Lancet. 2017;389(10066):255-65. https://doi. org/10.1016/S0140-6736(16)32517-X.

10. Horn L, Spigel DR, Vokes EE, Holgado E, Ready N, Steins M, Poddubskaya E, Borghaei H, Felip E, Paz-Ares L, Pluzanski A, Reckamp KL, Burgio MA, Kohlhäeufl M, Waterhouse D, Barlesi F, Antonia S, Arrieta O, Fayette J, Crinò L, Rizvi N, Reck M, Hellmann MD, Geese WJ, Li A, Blackwood-Chirchir A,
Healey D, Brahmer J, Eberhardt WEE. Nivolumab versus Docetaxel in previously treated patients with advanced non-small-cell lung Cancer: twoyear outcomes from two randomized, open-label, phase III trials (CheckMate 017 and CheckMate 057). J Clin Oncol. 2017;35(35):3924-33. https://doi. org/10.1200/JCO.2017.74.3062.

11. Gettinger SN, Wurtz A, Goldberg SB, Rimm D, Schalper K, Kaech S, Kavathas P, Chiang A, Lilenbaum R, Zelterman D, Politi K, Herbst RS. Clinical features and Management of Acquired Resistance to PD-1 Axis inhibitors in 26 patients with advanced non-small cell lung Cancer. J Thorac Oncol. 2018; 13(6):831-9. https://doi.org/10.1016/j.jtho.2018.03.008.

12. Campo M, Al-Halabi H, Khandekar M, Shaw AT, Sequist LV, Willers $H$. Integration of stereotactic body radiation therapy with tyrosine kinase inhibitors in stage IV oncogene-driven lung Cancer. Oncologist. 2016;21(8): 964-73. https://doi.org/10.1634/theoncologist.2015-0508.

13. Basler L, Kroeze SG, Guckenberger M. SBRT for oligoprogressive oncogene addicted NSCLC. Lung Cancer. 2017;106:50-7. https://doi.org/10.1016/j. lungcan.2017.02.007.

14. Laurie SA, Banerji S, Blais N, Brule S, Cheema PK, Cheung P, Daaboul N, Hao $D$, Hirsh V, Juergens R, et al. Canadian consensus: oligoprogressive, pseudoprogressive, and oligometastatic non-small-cell lung cancer. Curr Oncol (Toronto, Ont). 2019;26(1):e81-93.

15. lyengar P, Kavanagh BD, Wardak Z, Smith I, Ahn C, Gerber DE, Dowell J, Hughes R, Abdulrahman R, Camidge DR, Gaspar LE, Doebele RC, Bunn PA, Choy $H$, Timmerman $\mathrm{R}$. Phase II trial of stereotactic body radiation therapy combined with erlotinib for patients with limited but progressive metastatic non-small-cell lung cancer. J Clin Oncol. 2014;32(34):3824-30. https://doi. org/10.1200/JCO.2014.56.7412.

16. Gan GN, Weickhardt AJ, Scheier B, Doebele RC, Gaspar LE, Kavanagh BD, Camidge DR. Stereotactic radiation therapy can safely and durably control sites of extra-central nervous system oligoprogressive disease in anaplastic lymphoma kinase-positive lung cancer patients receiving crizotinib. Int J Radiat Oncol Biol Phys. 2014;88(4):892-8. https://doi.org/10.1016/j.jjrobp.2013.11.010.

17. Weickhardt AJ, Scheier B, Burke JM, Gan G, Lu X, Bunn PA Jr, Aisner DL, Gaspar LE, Kavanagh BD, Doebele RC, Camidge DR. Local ablative therapy of oligoprogressive disease prolongs disease control by tyrosine kinase inhibitors in oncogene-addicted non-small-cell lung cancer. J Thorac Oncol. 2012;7(12):1807-14. https://doi.org/10.1097/JTO.0b013e3182745948.

18. Al-Halabi H, Sayegh K, Digamurthy SR, Niemierko A, Piotrowska Z, Willers H, Sequist LV. Pattern of failure analysis in metastatic EGFR-mutant lung Cancer treated with tyrosine kinase inhibitors to identify candidates for consolidation stereotactic body radiation therapy. J Thorac Oncol. 2015; 10(11):1601-7. https://doi.org/10.1097/JTO.0000000000000648.

19. Yu HA, Sima CS, Huang J, Solomon SB, Rimner A, Paik P, Pietanza MC, Azzoli CG, Rizvi NA, Krug LM, Miller VA, Kris MG, Riely GJ. Local therapy with continued EGFR tyrosine kinase inhibitor therapy as a treatment strategy in EGFR-mutant advanced lung cancers that have developed acquired resistance to EGFR tyrosine kinase inhibitors. J Thorac Oncol. 2013:8(3):34651. https://doi.org/10.1097/JTO.0b013e31827e1f83.

20. Qian J, Nie W, Lu J, Zhang L, Zhang Y, Zhang B, Wang S, Hu M, Xu J, Lou Y, Dong Y, Niu Y, Yan B, Zhong R, Zhang W, Chu T, Zhong H, Han B. Racial differences in characteristics and prognoses between Asian and white patients with nonsmall cell lung cancer receiving atezolizumab: an ancillary analysis of the POPLAR and OAK studies. Int J Cancer. 2020;146(11):3124-33. https://doi.org/10.1002/ijc.32717.

21. Tamiya M, Tamiya A, Inoue T, Kimura M, Kunimasa K, Nakahama K, Taniguchi Y, Shiroyama T, Isa SI, Nishino K, Kumagai T, Suzuki H, Hirashima T, Atagi S, Imamura F. Metastatic site as a predictor of nivolumab efficacy in patients with advanced non-small cell lung cancer: a retrospective multicenter trial. PLoS One. 2018;13(2):e0192227. https://doi.org/10.1371/journal.pone.0192227.

22. Haratani K, Hayashi H, Chiba Y, Kudo K, Yonesaka K, Kato R, Kaneda H, Hasegawa Y, Tanaka K, Takeda M, Nakagawa K. Association of Immune-Related Adverse Events with Nivolumab Efficacy in non-small-cell lung Cancer. JAMA Oncol. 2018;4(3):374-8. https://doi.org/10.1001/jamaoncol.2017.2925.

23. Teraoka S, Fujimoto D, Morimoto T, Kawachi H, Ito M, Sato Y, Nagata K, Nakagawa A, Otsuka K, Uehara K, Imai Y, Ishida K, Fukuoka J, Tomii K. Early immune-related adverse events and association with outcome in advanced non-small cell lung Cancer patients treated with Nivolumab: a prospective cohort study. J Thorac Oncol. 2017;12(12):1798-805. https://doi.org/10.1016/ j.jtho.2017.08.022.

24. Hosoya K, Fujimoto D, Morimoto T, Kumagai T, Tamiya A, Taniguchi Y, Yokoyama T, Ishida T, Hirano K, Matsumoto H, Kominami R, Tomii K, Suzuki 
H, Hirashima T, Uchida J, Morita M, Kanazu M, Sawa N, Makio T, Hara S, Tamiya M. Association between early immune-related adverse events and clinical outcomes in patients with non-small cell lung Cancer treated with immune checkpoint inhibitors. Clin Lung Cancer. 2020;21(4):e315-28. https://doi.org/10.1016/j.cllc.2020.01.003.

25. Fujimoto D, Yoshioka H, Kataoka Y, Morimoto T, Kim YH, Tomii K, Ishida T, Hirabayashi M, Hara S, Ishitoko M, Fukuda Y, Hwang MH, Sakai N, Fukui M, Nakaji H, Morita M, Mio T, Yasuda T, Sugita T, Hirai T. Efficacy and safety of nivolumab in previously treated patients with non-small cell lung cancer: a multicenter retrospective cohort study. Lung Cancer. 2018;119:14-20. https://doi.org/10.1016/j.lungcan.2018.02.017.

26. Muchnik E, Loh KP, Strawderman M, Magnuson A, Mohile SG, Estrah V, Maggiore RJ. Immune checkpoint inhibitors in real-world treatment of older adults with non-small cell lung Cancer. J Am Geriatr Soc. 2019;67(5):905-12. https://doi.org/10.1111/jgs.15750.

27. Lichtenstein MRL, Nipp RD, Muzikansky A, Goodwin K, Anderson D, Newcomb RA, Gainor JF. Impact of age on outcomes with immunotherapy in patients with non-small cell lung Cancer. J Thorac Oncol. 2019;14(3):54752. https://doi.org/10.1016/j.jtho.2018.11.011

28. Landi L, D'Inca F, Gelibter A, Chiari R, Grossi F, Delmonte A, Passaro A, Signorelli D, Gelsomino F, Galetta D, et al. Bone metastases and immunotherapy in patients with advanced non-small-cell lung cancer. J Immunother Cancer. 2019;7(1):316. https://doi.org/10.1186/s40425-019-0793-8.

29. Briceno O, Lissina A, Wanke K, Afonso G, von Braun A, Ragon K, Miquel T, Gostick E, Papagno L, Stiasny K, et al. Reduced naive CD8(+) T-cell priming efficacy in elderly adults. Aging Cell. 2016;15(1):14-21. https://doi.org/1 0.1111 /acel.12384.

30. Desquilbet $L$, Margolick JB, Fried LP, Phair JP, Jamieson BD, Holloway M, Jacobson LP, Multicenter ACS. Relationship between a frailty-related phenotype and progressive deterioration of the immune system in HIVinfected men. J Acquir Immune Defic Syndr. 2009;50(3):299-306. https://doi. org/10.1097/QAl.0b013e3181945eb0.

31. Wherry EJ, Blattman JN, Murali-Krishna K, van der Most R, Ahmed R. Viral persistence alters CD8 T-cell immunodominance and tissue distribution and results in distinct stages of functional impairment. J Virol. 2003;77(8):491127. https://doi.org/10.1128/JVI.77.8.4911-4927.2003.

32. Victor CT-S, Rech AJ, Maity A, Rengan R, Pauken KE, Stelekati E, Benci JL, Xu B, Dada H, Odorizzi PM, et al. Radiation and dual checkpoint blockade activate non-redundant immune mechanisms in cancer. Nature. 2015; 520(7547):373-7. https://doi.org/10.1038/nature14292.

33. Dovedi SJ, Cheadle EJ, Popple AL, Poon E, Morrow M, Stewart R, Yusko EC, Sanders CM, Vignali M, Emerson RO, Robins HS, Wilkinson RW, Honeychurch J, Illidge TM. Fractionated radiation therapy stimulates antitumor immunity mediated by both resident and infiltrating polyclonal T-cell populations when combined with PD-1 blockade. Clin Cancer Res. 2017;23(18):5514-26. https://doi.org/10.1158/1078-0432.CCR-16-1673.

34. Theelen W, Peulen HMU, Lalezari F, van der Noort V, de Vries JF, Aerts J, Dumoulin DW, Bahce I, Niemeijer AN, de Langen AJ, et al. Effect of Pembrolizumab after stereotactic body radiotherapy vs Pembrolizumab alone on tumor response in patients with advanced non-small cell lung Cancer: results of the PEMBRO-RT phase 2 randomized clinical trial. JAMA Oncol. 2019;5(9):1276. https://doi.org/10.1001/jamaoncol.2019.1478.

35. Campbell AM, Cai WL, Burkhardt D, Gettinger SN, Goldberg SB, Amodio M, Kaech S, Krishnaswamy S, Decker $\mathrm{RH}$. Final results of a phase II prospective trial evaluating the combination of stereotactic body radiotherapy (SBRT) with concurrent Pembrolizumab in patients with metastatic non-small cell lung Cancer (NSCLC). Int J Radiat Oncol. 2019;105(1):S36-7. https://doi.org/1 0.1016/j.jijobp.2019.06.453.

36. Sharma P, Hu-Lieskovan S, Wargo JA, Ribas A. Primary, adaptive, and acquired resistance to Cancer immunotherapy. Cell. 2017;168(4):707-23. https://doi.org/10.1016/j.cell.2017.01.017.

37. Saleh $R$, Elkord E. Acquired resistance to cancer immunotherapy: role of tumor-mediated immunosuppression. Semin Cancer Biol. 2020;65:13-27. https://doi.org/10.1016/j.semcancer.2019.07.017.

38. Horvath $L$, Thienpont B, Zhao L, Wolf D, Pircher A. Overcoming immunotherapy resistance in non-small cell lung cancer (NSCLC) - novel approaches and future outlook. Mol Cancer. 2020;19(1):141. https://doi.org/1 $0.1186 / s 12943-020-01260-z$

39. Pathak R, Pharaon RR, Mohanty A, Villaflor VM, Salgia R, Massarelli E. Acquired resistance to PD-1/PD-L1 blockade in lung Cancer: mechanisms and patterns of failure. Cancers (Basel). 2020;12(12):3851. https://doi.org/1 0.3390/cancers 12123851.

40. Anagnostou V, Smith KN, Forde PM, Niknafs N, Bhattacharya R, White J, Zhang T, Adleff V, Phallen J, Wali N, Hruban C, Guthrie VB, Rodgers K, Naidoo J, Kang H, Sharfman W, Georgiades C, Verde F, Illei P, Li QK, Gabrielson E, Brock MV, Zahnow CA, Baylin SB, Scharpf RB, Brahmer JR, Karchin R, Pardoll DM, Velculescu VE. Evolution of Neoantigen landscape during immune checkpoint blockade in non-small cell lung Cancer. Cancer discovery. 2017;7(3):264-76. https://doi.org/10.1158/2159-8290.CD-16-0828.

41. Gettinger S, Choi J, Hastings K, Truini A, Datar I, Sowell R, Wurtz A, Dong W, Cai G, Melnick MA, du WY, Schlessinger J, Goldberg SB, Chiang A, Sanmamed MF, Melero I, Agorreta J, Montuenga LM, Lifton R, Ferrone S, Kavathas P, Rimm DL, Kaech SM, Schalper K, Herbst RS, Politi K. Impaired HLA class I antigen processing and presentation as a mechanism of acquired resistance to immune checkpoint inhibitors in lung Cancer. Cancer discovery. 2017;7(12):1420-35. https://doi.org/10.1158/2159-8290.CD-170593.

42. Zaretsky JM, Garcia-Diaz A, Shin DS, Escuin-Ordinas H, Hugo W, HuLieskovan S, Torrejon DY, Abril-Rodriguez G, Sandoval S, Barthly L, Saco J, Homet Moreno B, Mezzadra R, Chmielowski B, Ruchalski K, Shintaku IP, Sanchez PJ, Puig-Saus C, Cherry G, Seja E, Kong X, Pang J, Berent-Maoz B, Comin-Anduix B, Graeber TG, Tumeh PC, Schumacher TNM, Lo RS, Ribas A. Mutations associated with acquired resistance to PD-1 blockade in melanoma. N Engl J Med. 2016;375(9):819-29. https://doi.org/10.1056/ NEJMoa1604958.

43. George S, Miao D, Demetri GD, Adeegbe D, Rodig SJ, Shukla S, Lipschitz M, Amin-Mansour A, Raut CP, Carter SL, Hammerman P, Freeman GJ, Wu CJ, Ott PA, Wong KK, van Allen EM. Loss of PTEN is associated with resistance to anti-PD-1 checkpoint blockade therapy in metastatic uterine Leiomyosarcoma. Immunity. 2017;46(2):197-204. https://doi.org/10.1016/j. immuni.2017.02.001.

44. Koyama S, Akbay EA, Li YY, Herter-Sprie GS, Buczkowski KA, Richards WG, Gandhi L, Redig AJ, Rodig SJ, Asahina H, Jones RE, Kulkarni MM, Kuraguchi M, Palakurthi S, Fecci PE, Johnson BE, Janne PA, Engelman JA, Gangadharan SP, Costa DB, Freeman GJ, Bueno R, Hodi FS, Dranoff G, Wong KK, Hammerman PS. Adaptive resistance to therapeutic PD-1 blockade is associated with upregulation of alternative immune checkpoints. Nat Commun. 2016;7(1):10501. https://doi.org/10.1038/ncomms10501.

45. Huang RY, Francois A, McGray AR, Miliotto A, Odunsi K. Compensatory upregulation of PD-1, LAG-3, and CTLA-4 limits the efficacy of single-agent checkpoint blockade in metastatic ovarian cancer. Oncoimmunology. 2017; 6(1):e1249561. https://doi.org/10.1080/2162402X.2016.1249561.

46. Saleh R, Elkord E. Treg-mediated acquired resistance to immune checkpoint inhibitors. Cancer Lett. 2019;457:168-79. https://doi.org/10.1016/j.canlet.201 9.05.003.

47. Hou A, Hou K, Huang Q, Lei Y, Chen W. Targeting myeloid-derived suppressor cell, a promising strategy to overcome resistance to immune checkpoint inhibitors. Front Immunol. 2020;11:783. https://doi.org/10.3389/ fimmu.2020.00783.

48. Hui R, Gandhi L, Costa EC, Felip E, Ahn MJ, Eder JP, Balmanoukian AS, Leighl NB, Aggarwal C, Horn L, et al. Long-term OS for patients with advanced NSCLC enrolled in the KEYNOTE-001 study of pembrolizumab (pembro). J Clin Oncol. 2016;34(15):9026. https://doi.org/10.1200/JCO.2016.34.15_suppl. 9026.

49. Hellmann MD, Paz-Ares L, Bernabe Caro R, Zurawski B, Kim SW, Carcereny Costa E, Park K, Alexandru A, Lupinacci L, de la Mora JE, et al. Nivolumab plus Ipilimumab in advanced non-small-cell lung Cancer. N Engl J Med. 2019;381(21):2020-31. https://doi.org/10.1056/NEJMoa1910231.

\section{Publisher's Note}

Springer Nature remains neutral with regard to jurisdictional claims in published maps and institutional affiliations. 